Raf. J. Sci.,Vol.27, No.4 /Special Issue for the Third Scientific Conference of Biology, pp.19-32, 2018

\title{
Survey and Identification of some New Record Mushrooms in Erbil Governorate- Kurdistan Region-Iraq
}

\author{
Farid M. Toma \\ Hero M. Ismael \\ Nareen Q. Faqi Abdulla \\ Department of Biology/College of Science/ University of Salahaddin-Erbil
}

E-mail: $\underline{\text { fareed.toma@su.edu.krd, hero.ismael@su.edu.krd, nareen_qf@yahoo.com }}$

(Received $27 / 9 / 2018$; Accepted 1/ 11/2018)

\begin{abstract}
Sixteen species of Basidiomycota, which belong to sixteen genera were collected and identified from various areas in Erbil city of kurdistan region-Iraq, such as: Erbil city center, Barzan, Hanara, Heran, Khalefan, Koysnjaq, Salahaddin (Permum), Mergasur, Shaqlawa and Tawska. The identified genera and species include the followings: Agaricus bitorquis, Ampulloclitocybe clavipes, Bovista plumbea, Coprinus micaceus, Hebeloma mesophaeum, lyophyllum decastes, Mycena inclinata, Meruliopsis taxicola, Panaeolus papilionaceus, Pleurotus ostreatus, Polyporus arcularius, Russula turci, Schizophyllum commune, Scleroderma verrucosum, Trametes hirsuta and Vascellum pretense. Seven genera of the mushroom were new record in kurdistan region-Iraq, such as: Ampulloclitocybe clavipes, Bovista plumbea, lyophyllum decastes, Meruliopsis taxicola, Russula turci, Scleroderma verrucosum and Vascellum pretense. The aim of this research is to survey and identify Basidiomycota, which is a wild mushroom that grow in natural form in different seasons and different areas.
\end{abstract}

Keywords: Mushroom, Erbil, Russula turci and Scleroderma verrucosum.

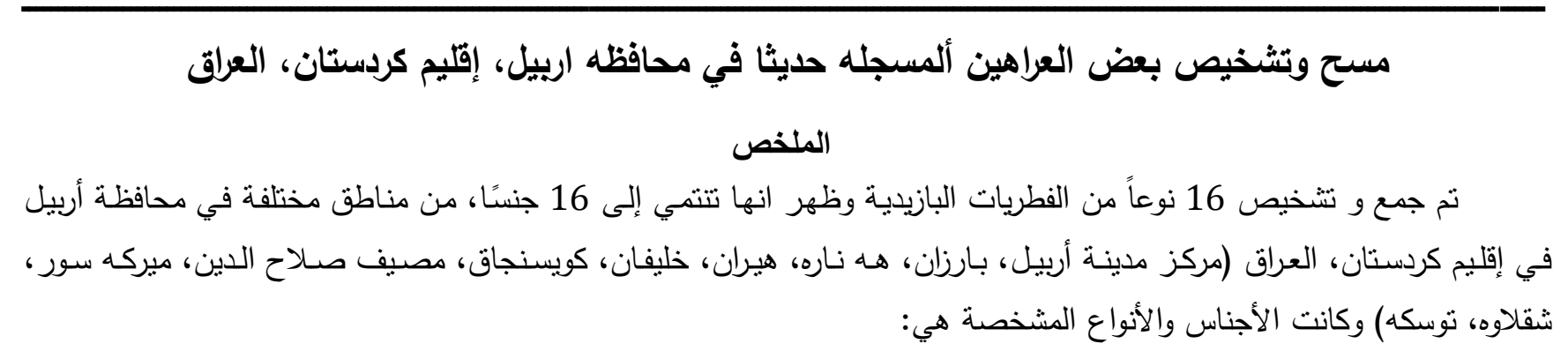

Agaricus bitorquis, Ampulloclitocybe clavipes,Bovista plumbea,Coprinus micaceus, Hebeloma mesophaeum, lyophyllum decastes, Mycena inclinata, Meruliopsis taxicola, Panaeolus papilionaceus, Pleurotus ostreatus, Polyporus arcularius, Russula turci, Schizophyllum commune,Scleroderma verrucosum,Trametes hirsuta and Vascellum pretense.

$$
\text { سجلت سبعة انواع من الفطريات لأول مرة في اربيل، كردستان العراق هي: }
$$

‘Meruliopsis taxicola ‘lyophyllum decastes ‘Bovista plumbea ‘Ampulloclitocybe clavipes

.Vascellum pretense g Scleroderma verrucosum ‘Russula turci

الكلمات الالة : Mushroom، اربيل ، Russula turci و Scleroderma verrucosum. 


\section{INTRODUCTION}

Mushrooms belong to Basidiomycota, the phylum is classified into 16 classes, and 52 orders (Hibbett et al., 2007). They are microfungi with distinguishing fruiting bodies, which can be large enough to be seen with the naked eye and to be picked by hand (Chang and Miles, 2004). They consist of hypha which form-interwoven web of tissue known as mycelium in the substrate upon which the fungus feeds. Most often their mycelia are buried in the tissue of a tree trunk, on a fallen log of wood or in other nourishing substrates (Ingold, 1993). Wild mushrooms are an important non-timber forest resource used by some societies, are mycophilic and their mode of utilization has been authenticated in many countries around the world (Thatoi and Singdevsachan, 2014). The practice of conventional hunting of mushroom from the wild when in season is still prevalent (Oso, 1975) Mushrooms have been commercially exploited in the whole world and may be gathered or cultivated from the wild (Boa, 2004).

Many genera of mushrooms are well utilized for food and they are rich in essential nutrients, such as carbohydrates, and have a low fat and oil content, and contain vitamins, proteins, fibres, mineral and various amino acids (Luangharn et al., 2014 and Bandara et al., 2015). They have been used in medicinal field such as: anticancer, antimicrobial, antioxidant, cholesterol lowering and immuno stimulatory effects (Benjarong et al., 2015). Eating wild mushrooms of proved quality and kinds is not a risk, but the danger is in indiscriminately eating all wild mushrooms, because some are edible and others are poisonous. People should not pick and eat any wild mushrooms but they should seek some kinds of mushrooms that can be recognized with ease and certainty and that are positively known to be good (Christensen, 1981).

Different species of mushroom were classified as poisonous and if ingested it represents risks to health. Ingestion of toxic mushrooms is invariably accidental and caused by misidentification of species (Karlson-Stiber and Persson, 2003; Flesch and Saviuc, 2004). Most toxins of mushroom, such as amatoxins are cytotoxic and cause harm to kidney and liver and or ellanine that is nephrotoxic (Wasser, 2002).

The aim of the present work is to survey and identify wild mushroom that grow in natural form in different seasons and different sites in Erbil Governorate, Kurdistan region-Iraq.

\section{Survey of mushrooms}

\section{MATERIALS AND METHODS}

Several genera of wild mushrooms were collected from different areas in Erbil Governorate within Kurdistan region, during March to June 2015 to 2017. These areas are Erbil city center (36 $11^{\prime} 28.19^{\prime \prime}$

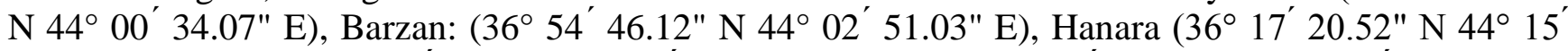

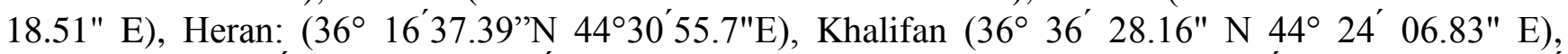

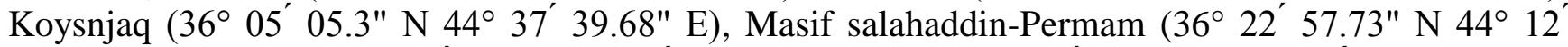

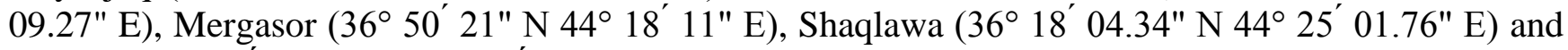
Tawska (36 $\left.22^{\prime} 39.77^{\prime \prime} \mathrm{N} 44^{\circ} 17^{\prime} 24.23^{\prime \prime} \mathrm{E}\right)$, as shown in (Fig.1), selected by green symbol. Followed by methods of collection, preservation and identification. 


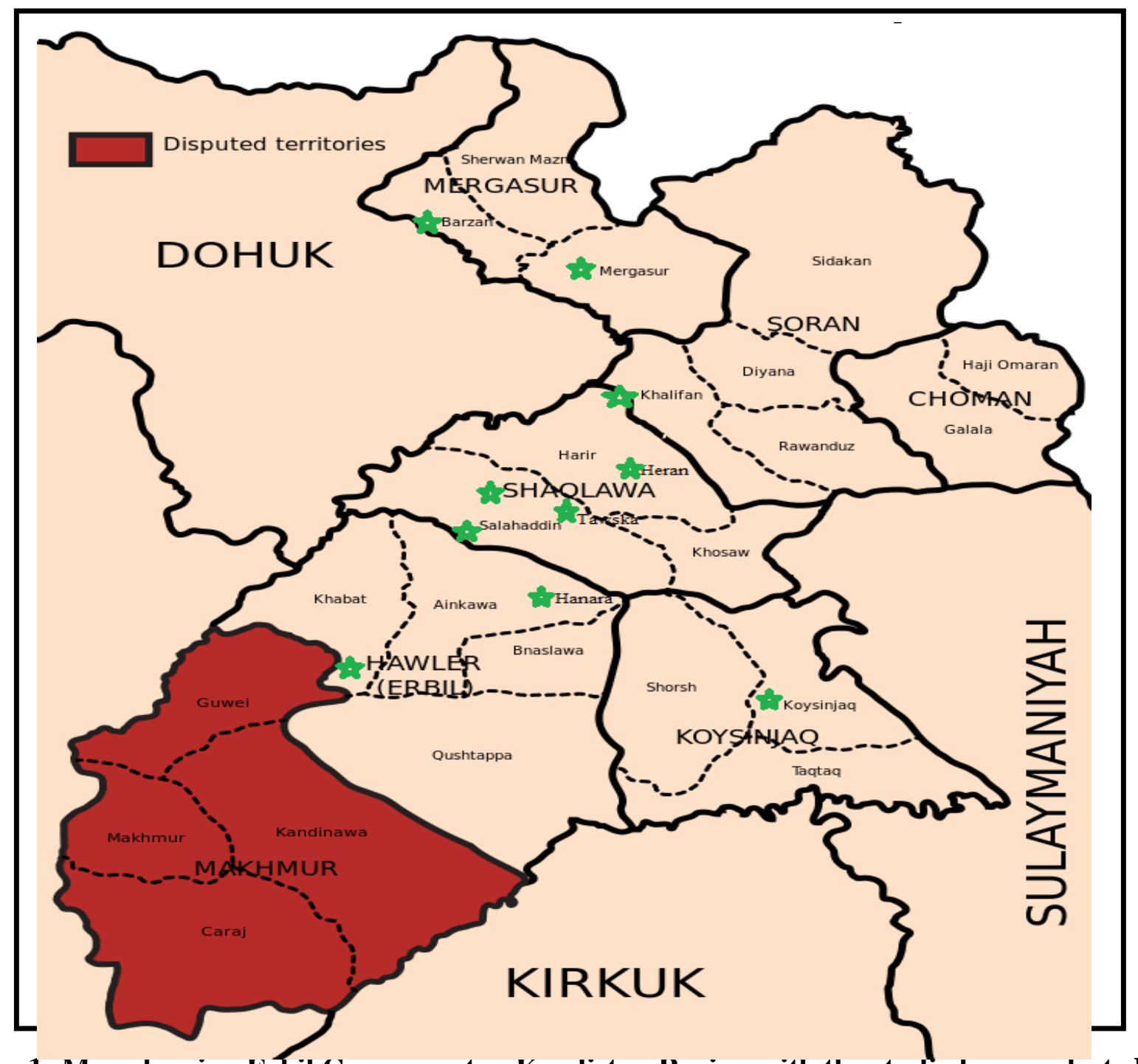

Fig. 1: Map showing Erbil Governorate - Kurdistan Region with the studied area selected by green symbol

\section{Characterization and identification of mushrooms}

Samples were found in damp places of forests, mountain areas and public gardens or in shade trees on the decayed roots and dead trees, then they were photographed and collected from their natural sites and kept in a box for storage until they reach laboratory for identification. The identification of the collected mushrooms was according to textbooks. To detect the basidia and basidiospore and measure their diameter by ocular lens, slides were made. According to Hawksworth et al., (1995) and Laessoe and Lincoff (1998), the photographs were made by digital camera and portable Olympus zoom camera measurements. Depending on keys used for identification, the macroscopic and microscopic characteristics of fruiting bodies are mentioned in description section of recorded genus.

\section{Keys used for identification of mushrooms}

Depending on the taxonomic keys, the texts that were used for identification of mushrooms, are as follows; Baldrian, (2007), Cocchia et al., (2006), Desjardin et al., (2015), Hall et al., (2003), Sanchez, 
(2010), Statements, (2000).

\section{The preservations of mushrooms}

For preservation of mushroom samples, which are collected and identified, Formal-acetic Alcohol solution (FAA) was used, which consist of: 13 formalin, $5 \mathrm{ml}$ of glacial acetic acid and $200 \mathrm{ml}$ of ethyl alcohol (50\%).

\section{RESULTS AND DISCUSSION}

The distribution and frequency of wild mushrooms, which were collected from Erbil Governorate, were illustrated in the data presented in (Table 1). A total of 16 species, 16 genera, 13 families, 3 orders, and 1 class of Basidiomycetes were identified in Erbil Governorate in Iraq-Kurdistan region. A lot of collections of basidiomycetes were made and studied their macro and micro-morphological characteristics. Seven genera of the mushroom samples were newly recorded in Kurdistan region-Iraq when compared with the researches of Iraq about mushroom, such as: Ampulloclitocybe clavipes, Bovista plumbea, lyophyllum decastes, Meruliopsis taxicola, Russula turci, Scleroderma verrucosum and Vascellum pretense. The classification and characteristics of each mushroom genera and species, collected from different area of Erbil-Kurdistan region-Iraq, are as the followings: (Note: The genera that are new records for the Iraq are indicated by * symbol).

\section{Kingdom: Fungi}

Phylum: Basidiomycota

Class: Basidiomycetes

\section{Order: Agaricales}

Family: Agaricaceae

Agaricus bitorquis (Pavement mushroom): (Fig.2: a-A)

Cap: It is $12 \mathrm{~cm}$; it is dry, smooth and white to yellowish, convex to flat.

Stalk: $5.5 \mathrm{~cm}$ in width and $2.3 \mathrm{~cm}$ in length, cylindrical to club-shape white and smooth, ring is present.

Gills: are free, very narrow, close, lights pink colors when young, become dark reddish-brown.

Spore print: is deep chocolate brown.

Spores: $5-7 \times 4-5 \mathrm{Mm}$ elliptical in shape and smooth

Habitat: Found alone or in small groups in garden and at road sides

Location: Heran (Cocchia et al., 2006)

Bovista plumbea * (Paltry puffball) (Fig. 2: a-B)

Fruiting body: is a small puffball mushroom, white when young and greyish in age, it is attached to the substrate by a tuft of mycelium.

Basidiocarp: is $3 \mathrm{~cm}$, sub spherical in shape, line in scattered to cluster in disturbed area. Smooth and stemless.

Spores: are subglobose to oval, with very finely warted surface $4.5-6.5 \mathrm{x} 4.5-5 \mathrm{Mm}$. pale brown.

Habitat: Found on humus leaves in Salahaddin (Permam)

Location: Salahaddin (Permum) (Desjardin, et al., 2015)

Scleroderma verrucosum * (Earth balls) (Fig. 2: a-C)

Cap: It is $7.2 \mathrm{~cm}$ in width and $9 \mathrm{~cm}$ in length, pale yellow to brown and covered with irregular brown scales. It has a stem-like projection and thin skin.

Spores: are $3 \times 2.5-2 \times 2.5 \mathrm{Mm}$, globose, smooth, without pedicel and released by raindrops and wind current, brownish spore dust

Habitat: Found on dead wood growing in dense clusters appear in fall and early winter

Location: Koysnjaq (Linoof, 1981) 


\section{Family: Bolbitiaceae}

Panaeolus papilionaceus (Petticoat mottlegill) (Fig. 2:a-D)

Cap: It is 4-6cm a cross, grayish brown, conical to bell shape with age, dry, smooth to silky when young, hairy and crack with age.

Stalk: is $10 \mathrm{~cm}$ in length and $0.5-1.0 \mathrm{~cm}$ in width, colored more or less like the cap, at the apex it is paler and toward the base is dark or turning reddish.

Gills: are attached to the stem or pulling away from it with maturity, grayish when young, but soon developing black area, eventually black overall, with whitish edge.

Spore print: is black or blackish.

Spores: are11-18.5x7.5-12 Mm more or less elliptical with spore, smooth

Habitat: Found in the dung of horses and cows

Location: Barzan (Statements, 2000)

Family: Hygrophoraceae

Ampulloclitocybe clavipes* (Club-footed clitocybe) (Fig. 2: a-E)

Cap: It is $5 \mathrm{~cm}$, it is convex and has small boss, and the colors are grey to brown

Stalk: is $3 \mathrm{~cm}$ in length $\mathrm{x} 1 \mathrm{~cm}$ in width volva absent, ring is absent, often bulbous at bottom. At first flat with slightly under turned margin and become vase-shape, smooth, brown to grayish brown, usually darker over the center and lighter towards the margin by maturity.

Gills: are running down the stem, whitish or creamy.

Spore print: is white.

Spores: are 6-8x 3.5 Mm, Megg-shape, smooth

Habitat: Saprobic, growing alone, scattered, commonly name club-foot

Location: Hanara (Bresinsky and Besl, 2004)

\section{Family: Hymenogastraceae}

Hebeloma mesophaeum (Veiled Poisonpie) (Fig. 2: a-F)

Cap: is $4.5 \mathrm{~cm}$ convex, bell-shape or nearly flat, sticky, flesh, brown to pinkish brown over the center often paler toward the margin.

Stem: is $6 \mathrm{~cm}$ in length $\mathrm{x} 0.3 \mathrm{~cm}$ in width long, thick, whitish at first, becoming brownish to brown, from the base up, with maturity.

Gills: attached to the stalk, close or crowded creamy or faintly pinkish when, become brownish.

Spore print: is brown to pinkish brown.

Spores: are $8.5-11 \times 5.7 \mathrm{Mm}$, oval nearly smooth

Habitat: found with various conifers, growing in winter and autumn

Location: Tawska (Beker, et al., 2016)

\section{Family: Lycoperdaceae}

Vascellum pretense* (Meadow Puffball) (Fig. 2: b-G)

Fruiting body: Is $3 \mathrm{~cm}$ in length and $4 \mathrm{~cm}$ in width, spiny, white to pale brown, globe-shape top part from the short, sterile stem part. It usually has a rather flatten top with large opening, through it the spores are released.

Spores: are smooth, elongated and colorless

Habitat: found in solitary or as a groups in grassy area

Location: Barzan (Bates, 2004) 


\section{Family: Lyophyllaceae}

lyophyllum decastes* (Fried chicken mushroom) (Fig.2: b-H)

Cap is $9-11 \mathrm{~cm}$ convex, becoming flat, moist when fresh, smooth, grayish brown to yellowish brown.

Stalk: Is $8 \mathrm{~cm}$ in length and $2 \mathrm{~cm}$ in width, smooth, whitish and becoming brownish toward the base. Veil and ring are absent.

Gills: are attached to stem, close, white and yellowing somewhat with age.

Spore print: are white in color.

Spores: are 4-6 Mm round or spherical, smooth

Habitat: usually growing in dense clusters in disturbed soil (landscaping), some found alone and some found in wood.

Location: Erbil city center gardens (Ainkawa) (Desjardin et al., 2015)

\section{Family: Mycenaceae}

Mycena inclinata (Clustered bonnet) (Fig.2: b-I)

Cap: is $4 \mathrm{~cm}$, broadly conical, becoming broadly bell-shaped, have central bump, the margin usually fringe-like teeth when young and in age become splitting, brown to yellowish brown. Grow in dung spring and autumn.

Stalk: is $10 \mathrm{~cm}$ in length and $0.4 \mathrm{~cm}$ in width.

Gill: is white to pale grayish, have decurrently attachment to the stem.

Spore print: is white.

Spores: are $7-9$ by $5-6 \mathrm{Mm}$, oval, smooth

Habitat: This fungus grows in clusters or alone on the well-decayed wood

Location: Hanara (Baldrian, 2007)

\section{Family: Pleurotaceae}

Pleurotus ostreatus (Oyster Mushroom) (Fig. 2: b-J)

Cap: is $5-7 \mathrm{~cm}$ in length convex, becoming flat, kidney shape to fan shape or nearly round if growing on the top of logs, pale to dark brown. Known as oyster mushroom, it is an edible mushroom.

Stalk: is primary and lateral (off-center) or absent when growing on trees or logs are solid, dry usually hairy, $3 \mathrm{~cm}$ in length and $1-8 \mathrm{~cm}$ in width whitish or downy at the base.

Gills: are runny down the stem.

Spore print: is white.

Spores: are 7-11x2-4Mm cylindric-ellipsoid, smooth

Habitat: found in garden and logs, it is white rot wood decay fungus

Location: Erbil city center gardens (Ainkawa) (Statements, 2000)

\section{Family: Psathyrellaceae}

\section{Coprinus micaceus (Mica cap) (Fig. 2: b-K)}

Cap: is oval when young, expanding to broadly convex or bell-shape, brown and pale brown at margin, granules.

Stem: is $7 \mathrm{~cm}$ in length and $0.5 \mathrm{~cm}$, equal, smooth, white, fibrous hollow.

Gills: are attached to the stem. Pale brown, becoming brown then black, it will begin to slowly dissolve into black by auto digestion.

Spore print: is black.

Spores: are 7x4Mm, smooth, suboval, having central pore 
Habitat: growing in clusters on rotting hardwood

Location: Shaqlawa (Kuo, 2008)

Family: Schizophyllaceae

Schizophyllum commune (Split-gill mushroom) (Fig. 2: b-H)

Cap: is $3-5 \mathrm{~cm}$, fan-shape, irregular to shell-shape, dry, white, under surface composed of gill-like folds that are split down in middle. Stemless.

Spore print: is white.

Spores: are 3-4x1-1.5M, cylinder to oval, smooth

Habitat: found alone or clusters on decaying hard wood

Location: Erbil city center (Ainkawa) (Tullio et al., 2008)

\section{Order: Polyporales}

Family: Polyporaceae

Meruliopsis taxicola* (Poroid crust mushroom) (Fig. 3-A)

Basidiocarp: Is irregular or effused, $17 \times 23 \mathrm{~cm}$ in length and the thickness is $4 \mathrm{~mm}$; margin is pale when narrow granulose and indistinct when mycelioid, the width is up to $1 \mathrm{~cm}$; have tan to black hymenium, waxy, deep is $2 \mathrm{~mm}$, it forms circular to angular pits, hyphae loosely woven next to the substrate, becoming vertically arranged and closely packed in the folds

Habitat: Found on pine log Bracket

Location: Khalifan (Bondartsev and Singer, 1941)

Polyporus arcularius (Spring Polypore) (Fig. 3-B)

Cap: is $8 \mathrm{~cm}$ convex to flat or shallowly depressed, dry, brown to golden brown scales. Have hexagonal or angular pores.

Fresh cap is creamy whitish. The cap is circular or kidney-shaped with wavy edge.

Stem: is slightly off center, $3.5 \mathrm{~cm}$ in length and $1.2 \mathrm{~cm}$ in width, stem gradually decrease in width or thickness at one end.

Spores: are white $7 \times 3.5 \mathrm{Mm}$ cylinderic, smooth.

Spore print: is white

Habitat: found on the dead wood, growing alone or as clusters

Location: Koysnjaq (Kuo, 2004)

Family: Phanerochaetaceae

Trametes hirsuta (Hairy bracket) (Fig. 3-C)

Cap: has structure like hair, it is found on dead woods. The width is $6 \times 3.5 \mathrm{~cm}$ and length is $0.3 \times 1 \mathrm{~cm}$, semicircular, irregularly bracket-shape or kidney shape. It has some other features, such as: very densely hair, radially curl, with other concentric zones of texture, zones with gray and whitish

Habitat: found on the deadwood alone or as cluster

Location: Erbil city center (Hakman destrict) (Roger, 2006)

\section{Order: Russulales}

Family: Russulaceae

Russula turci *(Brittlegills) (Fig. 4)

Cap: is $9 \mathrm{~cm}$ in diameter, flat and pink in color; the margin is paler and matt in shape.

Gills: are creamy to light brown, they connected at the base by cross veins, and the spores are light brown.

Stem: is thick and white in color 
Habitat: they grows beneath trees

Locaton: Mergasur (Garnweidner, 1994)

Table 1: Collected mushrooms from Erbil-Kurdistan region-Iraq

\begin{tabular}{|c|c|c|c|c|c|}
\hline 馬 & ) & $\frac{0}{0}$ & Family & Scientific name & Common name \\
\hline \multirow{16}{*}{ 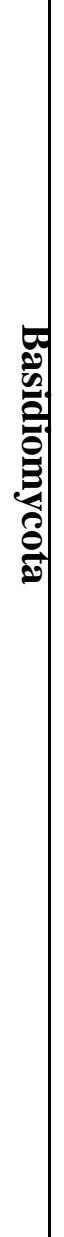 } & \multirow{16}{*}{ 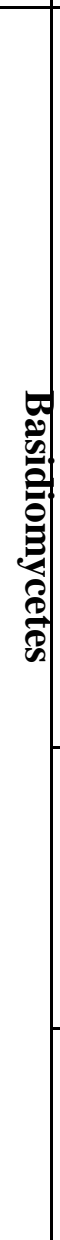 } & \multirow{12}{*}{ 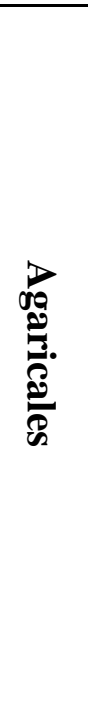 } & \multirow{3}{*}{ Agaricaceae } & Agaricus bitorquis & Pavement Mushroom \\
\hline & & & & Bovista plumbea & Paltry puffball \\
\hline & & & & Scleroderma verrucosum & Earth balls Mushroom \\
\hline & & & Bolbitiaceae & Panaeolus papilionaceus & Petticoat mottlegill \\
\hline & & & Hygrophoraceae & Ampulloclitocybe clavipes & Club-footed clitocybe \\
\hline & & & Hymenogastraceae & Hebeloma mesophaeum & Veiled Poisonpie \\
\hline & & & Lycoperdaceae & Vascellum pretense & Meadow Puffball \\
\hline & & & Lyophyllaceae & lyophyllum decastes & Fried chicken Mushroom \\
\hline & & & Mycenaceae & Mycena inclinata & Clustered bonnet \\
\hline & & & Pleurotaceae & Pleurotus ostreatus & Oyster Mushroom \\
\hline & & & Psathyrellaceae & Coprinus micaceus & Mica cap Mushroom \\
\hline & & & Schizophyllaceae & Schizophyllum commune & Split-gill Mushroom \\
\hline & & \multirow{3}{*}{ 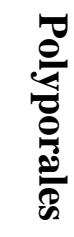 } & \multirow{2}{*}{ Polyporaceae } & Meruliopsis taxicola & Poroid crust Mushroom \\
\hline & & & & Polyporus arcularius & Spring Polypore \\
\hline & & & Phanerochaetaceae & Trametes hirsuta & Hairy bracket Mushroom \\
\hline & & 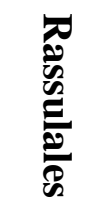 & Russulaceae & Russula turci & Brittlegills Mushroom \\
\hline
\end{tabular}

Our results are close to other researches, such as: Abou-Zeid and Altalhi (2006), who collected and identified several genera and species of basidiomycota from seven localities in Al-Taif Governorate-Saudi Arabia, which includes: Agaricus spp., Lepiota spp., leurotus ostreatus, Pleurotus cornucopiae, Coprinus comatus, Agrocybe cylindracea, Podaxis pistillaris, Inocybe splendens, Phaeolepiota aurea and Boletus edulis. Owaid et al., (2014), collected and identified different species from different villages of Heet district, Anbar province, Iraq, such as Armillaria mellea, Agaricus spp., Pleurotus spp., Calvatia sp., Coprinus disseminates, Teleport sp., Fomes sp., Lepiota sp. and Morchella sp. Toma et al., (2013), who collected and identified twenty-nine genera of basidiomycota from different areas in Erbil Governorate in kurdistan region-Iraq, such as: Agaricus spp., Collybia spp., Crepidotus sp., Coprinus spp., Clitocybe spp., Cortinarius spp., Craterellus sp., Exidia sp., Fomes 
spp., Galerina sp., Hebeloma sp., Helvella sp., Auricularia auricula-judae, Hygrocybe pratensis, Inocybe sp., Lactarius spp., Laccaria sp., Mycena sp., Peziza sp., Psathyrella sp., Panellus sp., Pluteus sp., Paxillus atrotomentosus, Scutellinia scutellata, Trichloma spp., Tyromyces spp., Lepiota sp. and Cystoderma. Adebiyi and Yakubu, (2016), who collected and identified different species of mushrooms among different substrates which include soils, bark of trees, dead wood/trees and dead leaves, in Ado and Ikere local government areas of Ekiti State, Nigeria, include Schizophyllum, Polyporus spp., Squarrosulus, Termitomyces robustus, Psathyrella candolleana, Lactinus piperatus, Lentinus tuberregium, Termitomyces mammiformi, Hydnochaete spp, Agaricus campestris and Lentinus spp., Auricularia spp., Chlorophyllum spp., Trichaptum biforme, Ganoderma applanatum, Coprinus nivenus, Cyathus spp., Geastrum spp. and Stereum spp. Aziz and Toma (2012), collected mushrooms from mountain areas in Sulaimani, Soran, Joman, Sedakan districts Qandil and Zalm village Amad Hawa, they identified several genera and species of basidiomycetes, such as: Agaricus, Macrolep, Cystoderma amianthinum, Crepidotus variabilis, Inocybe godeyi, Hypholoma, Entoloma, Clitocybe, Tricholoma, Micromphale, Mycena, Pleurotus, Panaeolus, Stereum, Lactarius, Phellinus, Chondrostereum, Fomes, Trametes, Fomitopsis and Paxilus corrugatus. Suliaman, et al., (2017), who collected macrofungi samples from different localities within Iraqi Kurdistan region - Northern Iraq. Seven basidiomycetous macrofungal species from seven genera, six families and two orders: Inocybe flocculosa, Pleurotus nebrodensis, Psathyrella spadiceogrisea, Schizophyllum commune, Volvopluteus gloiocephalus (Agaricales), Lentinus tigrinus and Trametes trogii (Polyporales) were reported from Iraqi Kurdistan. These macrofungal species are recorded for the first time from Iraq.

Our result disagree with those of Rattan and Abdullah (1976), who found seven species of woodrot Aphyllophorales collected from the pine forest in northern Iraq are described and illustrated. Out of these, Gloeocystidiellum luridum, Ampelomyces submolaris, Athelia acrospora, Amphinema tomentellastrum, stereum sanguinolentum and Asterostroma medium are new records for Iraq while Galzinia cystidiata is proposed as new species and Rattan et al., (1978), who collected and identified different types of fungi causing disease and decays of trees in Iraq, such as: Phlebia roumegueri, Amphinema byssoides, Gloeocystidiellun zawitense, Phellinus pini, Coriolus versicolor Phanerochaete gigantea Ilirschioporus abietinus, Gloeoporus adustus Stereum rugosum. Al-Khesraji et al., (2017), who made a survey on macrofungi was carried out in Al - Alam and Tikrit provinces from Tikrit district in Salahadin governorate / north central Iraq. It has been found macrofungal species belonging to 7 genera, 6 families and 3 orders were identified. These species are Coprinellus disseminatus, Ganoderma lucidum, Lichenomphalia umbellifera, Montagnea arenaria, Phellinus pomaceus, Podaxis pistillaris and Trametes trogii. All these fungi are described for the first time from Salahadin Governorate. Owaid et al., (2018), who identified a rare mushroom genus, Marasmius sp., for the first time in Iraq. Others, Clitocybe sp., for the first time in the studying area, and Agaricus spp. (edible), were also recorded in Heet city. All genera were collected from different locations (three gardens) in the center of Heet district. 

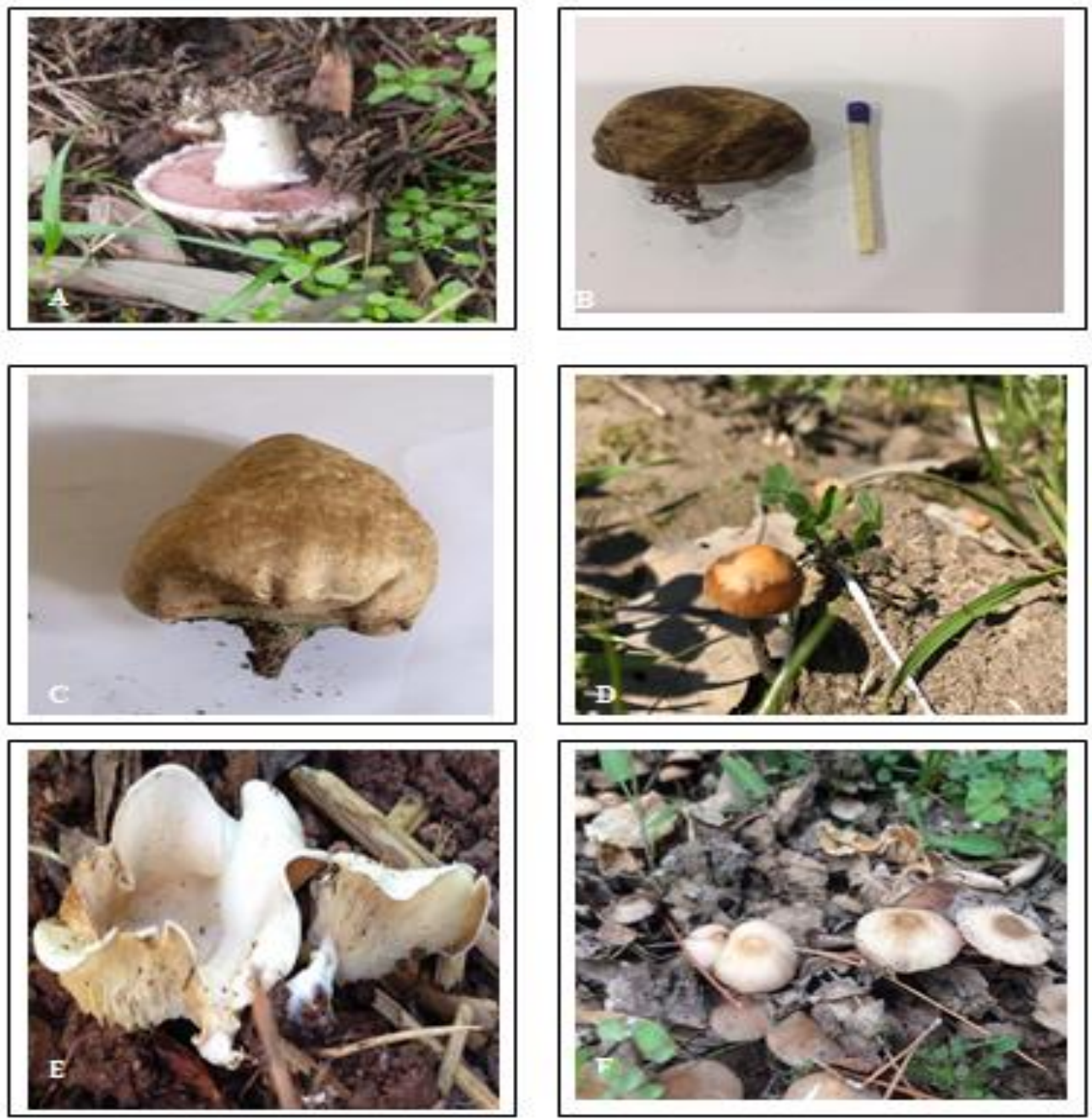

Fig.(2: a): Different genera belong to order: Agaricales
A. Agaricus bitorquis
B. Bovista plumbea
C. Scleroderma verrucosum
D. Panaeolus papilionaceus
E. Ampulloclitocybe clavipes
F. Hebeloma mesophaeum 

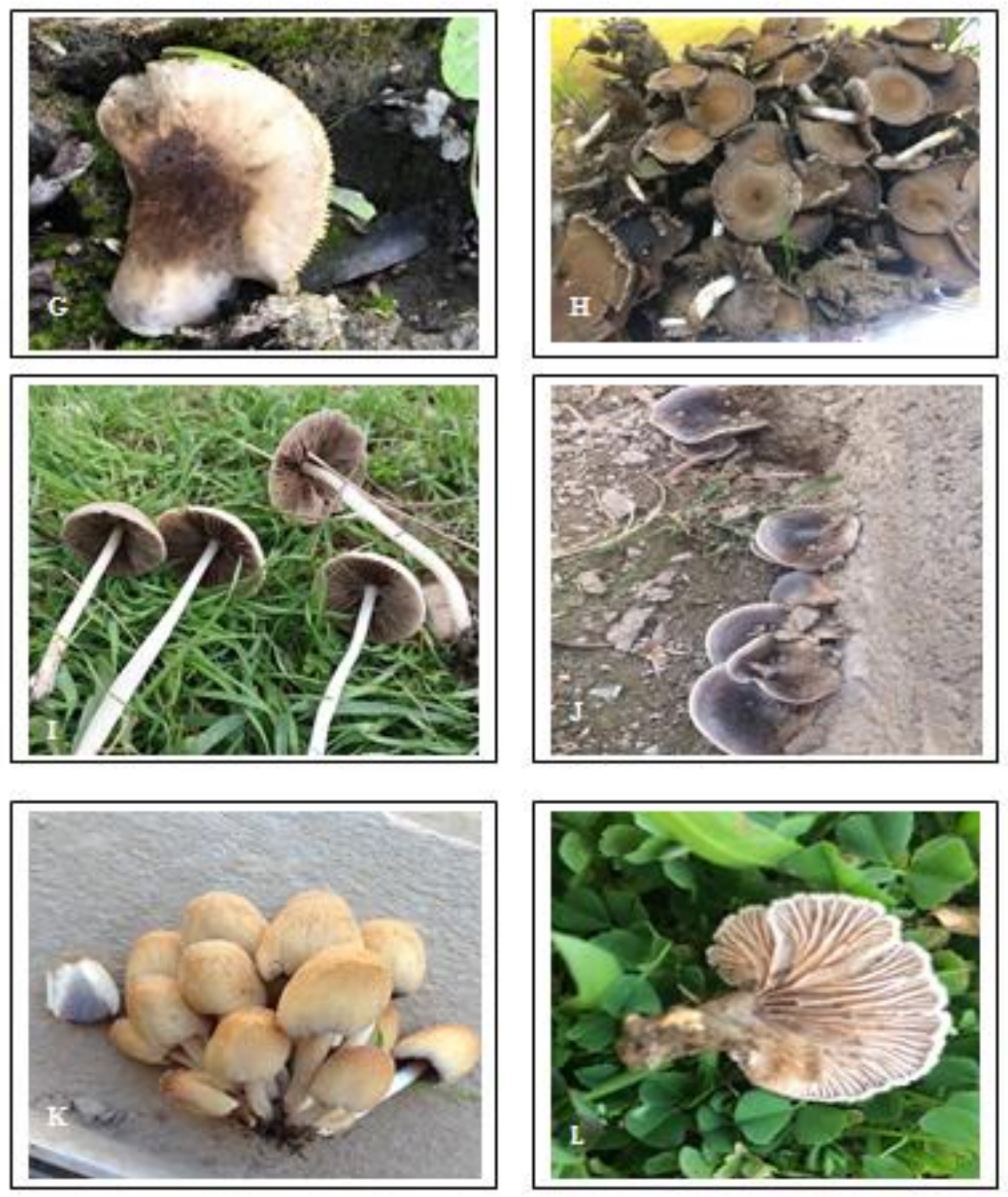

Fig. (2: b): Different genera belong to order: Agaricales
G. Vascellum pretense
H. lyophyllum decastes
I. Mycena inclinata
J. Pleurotus ostreatus
K. Coprinus micaceus
L. Schizophyllum commune 

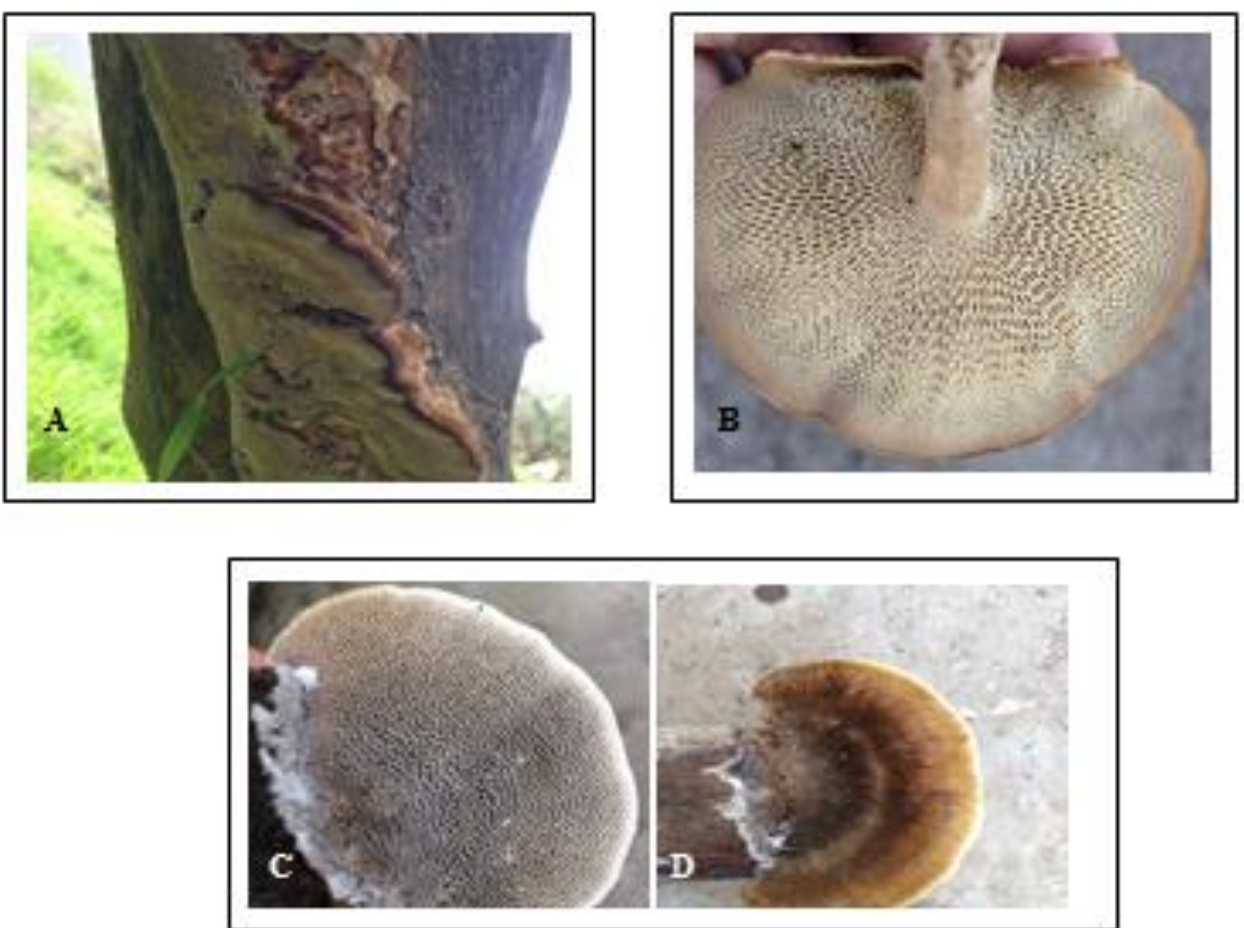

Fig. 3 : Different genera belong to order: Polyporales
A. Meruliopsis taxicola
B. Polyporus arcularius
C. Trametes hirsuta

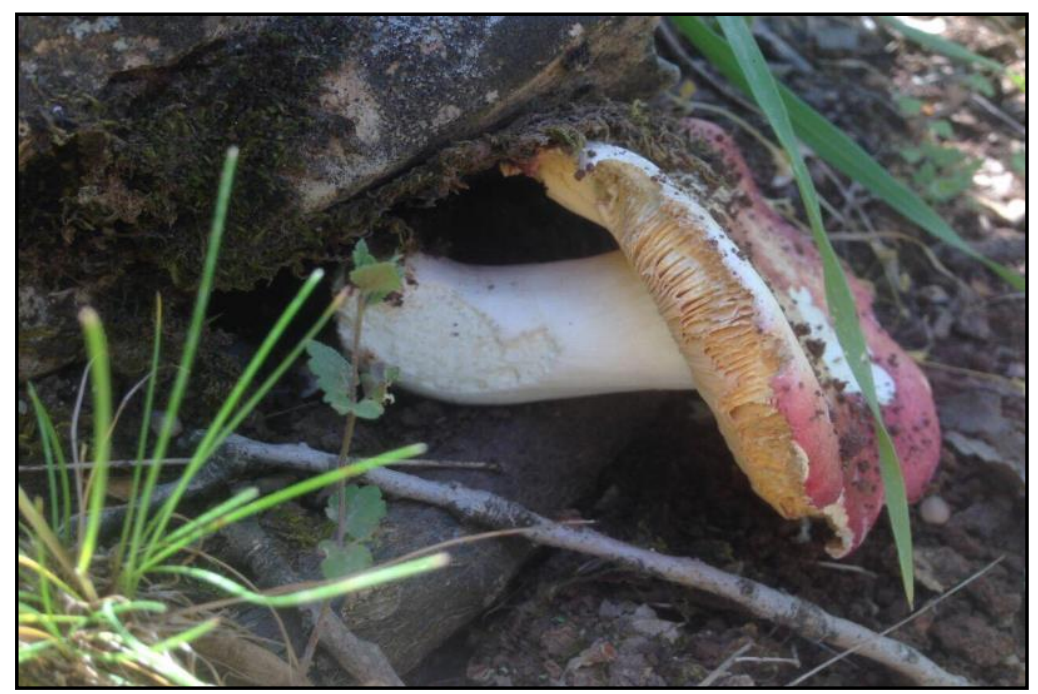

Fig. 4: Belong to order: Russulales Russula turci 


\section{REFERENCES}

Abou-Zeid, A.M.; Altalhi, A.E. (2006). Survey of some mushrooms in al-taif governorate of Saudi Arabia. World J. Agric. Sci., 2(1), 1817-3047.

Adebiyi, A.O.; Yakubu, H.O.(2016). A survey of mushrooms in two local government areas of Ekiti State, Nigeria. Original Research Paper. Donnish J. Agricultural Research. 3(2),013-016.

Al-Khesraji, T.O.; Shugran, A.H.M.; Augul, R.S. (2017). Some Basidiomycota Macrofungal Species from Salahadin Governorate (North Central Iraq), with the Addition of Four New Species to Iraq. Int. J. Curr. Res. Biosci. Plant Biol. 4 (10), 74-84.

Aziz, F.H.; Toma, F.M.(2012). First observations on the mushroom in Mountain Area of Iraqi Kurdistan Region. J. Advanced Laboratory Research in Biology. 3,(4).

Baldrian, P. (2007). Differential degradation of oak. Leaf litter by litter-decomposing basidiomycetes. Research in Microbiology. 158(5), 447 p.

Bandara, A.R.; Rapiord, S.; Bhat, D.J.; Kakumyana, P.; Chamyuang, S.; Jianchu, X.U.; Kevin, D.H. (2015). Polyporus umbellatus, an edible-medicinal cultivated mushroom with multiple developed health-care products as food, medicine and cosmetics: a review. Cryptogamie Mycologie. 36(1), 3-42.

Bates, S.T. (2004). "Arizona Members of the Geastraceae and Lycoperdaceae (Basidiomycota, Fungi)". Masters Thesis. Arizona State University: Tempe, AZ. 445 p.

Beker, H.J.; Eberhardt, U.; Vesterholt, J. (2016). Hebeloma (Fr.) P. Kumm. Edizioni Tecnografica: Lomazzo, Italy. $1217 \mathrm{p}$.

Benjarong, T.; Rapior, S.; Kevin, D.H.; Kathrin, W.; Stadler, M. (2015). Hericium erinaceus, an amazing medicinal mushroom. Mycological Progress. 14, 91.

Boa, E. (2004). Wild Edible Fungi: A Global Overview of their Use and Importance to People. NonWood Forest Products Series, No. 17, FAO, Rome.

Bondartsev, A.; Singer, R. (1941). Zur Systematik der Polyporaceae. Annales Mycologici. Merulioporia taxicola (Pers.). 39(1), 43-65.

Bresinsky, A.; Besl, H. (2004). A color Atlas of poisonous fungi. A handbook for pharmacist, Doctors and Biologists. CRC Press. pp. 124-125.

Chang, S.T.; Miles, P.G. (2004). "Mushrooms Cultivation, Nutritional Value, Medicinal Effect and Environmental Impact". $2^{\text {nd }}$ ed., CRC Press, Boca Raton, 450 p.

Christensen, C.M. (1981). "Edible Mushrooms". $2^{\text {nd }}$ ed., Printed in the United States of America, 118 p.

Cocchia, L.; Vescovia, L.; Petrinid, L.E.; Petrini, O. (2006). Heavy metals in edible mushrooms in Italy. Food Chem. 98(2), 277-84.

Desjardin, D.E.; Wood, M.G.; Stevens, F.A. (2015). "California Mushroom". The comprehensive identification Guid. Timber press. Portland. OR. 560 p.

Flesch, F.; Saviuc, P. (2004). Intoxication par les champignon: princi-paux syndromes et traitment. EMC-Médecine. 1, 70-9.

Garnweidner, E. (1994). "Mushrooms and Toadstools of Britain and Europe". Collins.

Hall, I.R.; Stephenson, S.L.; Buchanan, P.K.; Yun, W.; Cole, A.L.J. (2003). "Edible and Poisonous Mushrooms of the World". Printed through Color craft Ltd., Hong Kong. 370 p.

Hawksworth, D.L.; Kirk, P.M.; Sutton, B.C.; Pegler, D.N. (1995). "Ainsworth and Bisby's Dictionary of the Fungi". $8^{\text {th }}$ ed., CAB International, Walling Ford, U.K., 616 p.

Hibbett, D.S.; Binder, M.; Bischoff, J.F. (2007). A higher-level phylo- genetic classification of the fungi. Mycol Res; 111, 509- 547.

Ingold, C.T.(1993). "The Biology of Fungi". $6^{\text {th }}$ ed. Chapman and Hall, Iowa Conservation Education Council. pp. 197-206. 
Karlson-Stiber, P. (2003). Cytotoxic fungi an overview. Toxicon, 42 (4), 339-49.

Kuo, M. (2004). Polyporus badius. Mushroom Expert.com.

Kuo, M. (2008). Coprinellus micaceus. Retrieved from the Mushroom Expert. Com Website: http://www.Mushroomexpert.com/ coprinellus micaceus.html.

Laessoe, T.; Lincoff, G.(1998). "Mushrooms". (Eyewitness Handbooks) Kyodo Printing Co., Singapore, $303 \mathrm{p}$.

Lino, O. (1981). "National Audabon Society field guide to North American Mushroom". 826 p.

Luangharn, T.; Hyde, K.D.; Chukeatirote, E. (2014). Proximate analysis and mineral content of Laetiporus sulphureus strain MFLUCC 12-0546 from northern Thailand. Chiang Mai. J. Sci. 41, 765-770.

Oso, B.A. (1975). Mushrooms and yoruba people of Nigeria. Mycologia, 67, 311-319.

Owaid, M.N.; Mizban, M.M.; Tan, W.C.(2014). First collection and identification of wild mushrooms in Western Iraq. J. Advanced Laboratory Research in Biol. V( II), 29-34.

Owaid, M.N.; Seephueak, P.; Attallah, R.R.(2018). Recording novel mushrooms in Heet district, Iraq. Songklanakarin J. Sci. Technol. 40 (2), 367-369.

Rattan, S.S.; Abdullah, S.K. (1976). Studies on the wood rot fungi of Iraq. Indian Phytopatholgy, 3 (3), 296-302.

Rattan, S.S.; Abdullah, S.K.; Ismail, A.L.S.(1978). Studies on fungi causing disease and decays of trees in Iraq. Sonderdruck aus/Tirage a part de. Nova Hedwigia XXIX.

Roger, P. (2006). "Mushroom". Pub. McMilan. ISBNO-330-44237-6p.317.

Sanchez, C.(2010). Cultivation of Pleurotus ostreutus and other edible mushrooms. Appl. Microbial Biotechnical. 85(5),1321-37.

Statements, P. (2000). "The Role of Mushroom in Nature. Growing Gourmet and Medicinal Mushroom". Chapter 2. pp. 10-11.

Suliaman, S.Q.; Khesraji, T.O.; AL- Hassan, A.A.(2017). New records of basidiomycetous macrofugi from Kurdistan region - Northern Iraq. African J. Plant Scie.,11(6), 209-219.

Thatoi, H.; Singdevsachan, S.K.(2014). Diversity, nutritional composition and medicinal potential of Indian mushrooms: A review. African J. Biotechnol. 13, 523-545.

Toma, F.M.; Ismael, H.M.; Faqi Abdulla, N.Q. (2013). Survey and Identification of Mushrooms in Erbil Governorate. Research J. Environmental and Earth Scie. 5(5), 262-266.

Tullio, V.; Mandras, N.; Banche, G.; Allizand, V; Gaido, E.; Ronana, J.; Cuffini, A.M.; Carlone, N.A. (2008). Schizophyllum commune: an unusual agent of bronchopneumonia in immunecompromised patient. Medical Mycology. 46,735.738.

Wasser, S.P. (2002). Review of medicinal mushrooms advances: good news from old allies. Herbal Gram., 56, 28-33. 